\title{
Uncommon Preservation: Common Law Recognition of Admiralty Jurisdiction in Seamen's Wage and Hypothecation Cases
}

\author{
Rebecca Emily Rapp $\dagger$
}

From the fifteenth and early part of the sixteenth centuries onward, common law courts lost prominence as newer courts began to exercise jurisdiction over matters that had once been in the exclusive domain of the common law courts. The reduction in common law jurisdiction was so severe that one historian wrote, "Had the common law courts continued to dwindle and have found no effective ways of attracting back business, then the chancery and conciliar courts would have dealt with the bulk of the legal work throughout the country."

Common law courts fought against this decline (and their own demise) by developing ways to enlarge the scope of their jurisdiction and attract litigation that might have gone elsewhere. ${ }^{2}$ Many historians have discussed the struggle to retain jurisdiction by common law courts as a product of the fact that it is a common error among courts to value their own justice over the justice delivered by other institutions. These historians have dismissed the use of legal fictions by common law courts and stated that common law judges were alarmed

$\dagger$ B.A. 1996, The University of Chicago; M. Sc. 1997, The University of Oxford; J.D. 2000, The University of Chicago.

1 Marjorie Blatcher, The Court of King's Bench 1450-1550: A Study in Self-help vii, 32 (Athlone 1978) (investigating the workings of the King's Bench and finding "an unsatisfactory little court seemingly in decline but not without portents of recovery").

2 The courts developed the writ of latitat and the so-called Bill of Middlesex to fend off jurisdictional challenges of the courts of equity, and they used writs of prohibition and then the Parliamentary sanction to limit the jurisdiction of (and competition from) the Court of Star Chamber and Court of Requests, which attracted litigants by respectively providing a "less costly, less hazardous, and more expeditious" forum and "more intelligent and cheaper procedure." L.S. Leadam, ed, Select Cases Before the King's Council in the Star Chamber Commonly Called the Court of Star Chamber: A.D. 1477-1509 1xviii (Selden Society 1903); I.S. Leadam, ed, Select Cases in the Court of Requests: A.D. 1497-1569 xlvi (Selden Society 1898).

The techniques common law courts developed were not merely procedural tricks but involved legal fictions that actually changed substantive law. For example, in contract cases, common law courts expanded the medieval writ of assumpsit and presumed the existence of a promise from the fact of a debt to allow debts to be recovered in common law courts, even though such actions would otherwise fall outside of the court's jurisdiction. See W.S. Holdsworth, $3 \mathrm{~A}$ History of English Law 443 (Little, Brown 3d ed 1923). See, for example, Slade's Case, 4 Coke Report 92b, 76 ER 1074 (KB 1602) (presuming existence of a promise from the fact of a debt and allowing assumpsit to be brought on a simple promise to pay money). 
"by the loss of business which the development of the law in the King's Bench was causing.",

Despite its widespread acceptance, the suggestion that common law judges restricted non-common law courts merely to preserve their own jurisdiction is not supported by direct evidence. This evidentiary silence is not surprising given the reluctance of judges to admit that they acted for reasons outside the law. Nor is the silence fatal-it makes sense to conclude that judges tried to increase their power and incomes by expanding their courts' jurisdiction-particularly because judicial salaries were taken from court fees.

But the fact that the lack of evidence can be rationalized does not mean that the current theories of judicial self-aggrandizement should be accepted blindly. The only way to know whether these theories are correct is to analyze case law-and what judges actually did-during this period. Closer examination of what the common law courts actually did will provide better evidence of what motivated common law judges.

To that end, this Comment examines seamen's wage and hypothecation cases from after the English Revolution until around $1800{ }^{4}$ These cases are interesting because they undermine the theory that common law courts were only concerned with protecting their own jurisdiction. ' Common law courts often allowed Admiralty courts to exercise jurisdiction over seamen's wage and hypothecation cases, even when Admiralty jurisdiction was formally precluded by statute.

An examination of seamen's wage and hypothecation cases suggests that common law courts did not myopically cling to their own jurisdiction without considering the benefits of their non-common law counterparts. Rather, as Charles Gray described of this period,

it was more deeply federalistic [and] ... [j] urisdiction was taken more seriously ... because the mixed character of the system was

3 A.W.B. Simpson, A History of the Common Law of Contract: The Rise of the Action of Assumpsit 291 (Oxford 1975); Theodore F.T. Plucknett, A Concise History of the Common Law 644-45 (Butterworth 5th ed 1956).

4 Webster's Third New International Dictionary defines "hypothecate" as "to pledge without delivery of title or possession; to pledge (a ship) by a bottomry [a contract in the nature of a mortgage] bond." Philip Babcock Gove, ed, Webster's Third New International Dictionary 1117 (Merriam-Webster 1986). See Part I.A for a description of hypothecation.

5 For example, in Benzen $v$ Jeffries, 1 Lord Raymond 152, 91 Eng Rep 999 (KB 1697), a common law court held that the Admiralty court, not the common law court, was the proper court to hear a case regarding hypothecation-even though the Admiralty Jurisdiction Act (discussed in Part I.B) provided strong grounds for rejecting Admiralty jurisdiction.

6 For a general discussion of common law preservation of Admiralty jurisdiction, see Part II. See, for example, Ross v Walker, 2 Wilson Rep 264 (KB 1795) (allowing pilot to bring suit in Admiralty court to recover wages); Menetone v Gibbons, 3 Term Rep 267, 100 Eng Rep 568 (KB 1789) (recognizing Admiralty jurisdiction over hypothecation agreement that parties entered into on land). 
perceived as an essential and legitimate feature of it [and t]he common law [had] ... a special trust to keep all parts, including itself, in proper channels.

Ultimately, these cases indicate that common law judges may have seen themselves as stewards of an intertwined and complex judicial system, rather than as zealous adherents to the common law courts on which they served.

The social and political environment in which common law courts were operating emphasized the importance of encouraging English industry and commerce. The framework that common law courts developed to preserve Admiralty jurisdiction supported contemporary maritime business practices and helped distribute the costs created by the unique structure of maritime relationships. Taken together, these factors suggest that common law judges-though perhaps not explicitly concerned with efficiency-were cognizant of their role in facilitating productive economic relationships.

This Comment's examination of seamen's wage and hypothecation cases is intended to contribute to current understanding about the relationship between English common law and non-common law courts. It is meant to inspire, at the very least, a moment of hesitation about the widespread assumption that English judges merely wanted to expand the scope of their own jurisdiction.

Part I describes the structure of maritime relationships and explains why seamen's wage and hypothecation cases fell outside the statutorily defined scope of Admiralty jurisdiction. Part II describes the framework common law courts developed to preserve Admiralty jurisdiction in seamen's wage and hypothecation cases. And Part III

7 Charles Gray, 1 The Writ of Prohibition: Jurisdiction in Early Modern English Law xv (Oceana 1994).

8 The purpose of this Comment is limited to describing one aspect of the relationship between common law and Admiralty courts during the period from after the English Revolution until the nineteenth century. To the extent that this paper employs economic concepts, it provides a positive rather than a normative analysis of law. It attempts to "explain legal rules and outcomes as they are rather than to change them to make them better." Richard A. Posner, Economic Analysis of Law 27 (Little, Brown 5th ed 1998) (explaining the difference between positive and normative analysis of law).

Additionally, this Comment does not make broader claims about the U.S. legal system. In some sense, seamen's wage and hypothecation cases endow pragmatic, efficiency arguments with a historical pedigree and demonstrate that fostering productive business relationships was an important goal of the common law courts from which our own system evolved.

It may be possible to use this argument to make broader claims about the legitimacy and importance of pragmatic concerns in the U.S. system. However, it would take direct evidence, not provided in this Comment, to make these claims. Though the U.S. system evolved from the British common law system, some of the features of the former-most notably, Admiralty jurisdiction-were reactions to, rather than extensions of, the English common law system. 
examines why common law courts preserved Admiralty jurisdiction at the expense of their own jurisdiction.

\section{THE STATUTORY PURVIEW OF ADMIRALTY JURISDICTION OVER MARITIME RELATIONSHIPS}

England began an intense phase of international expansion during the Elizabethan age and the seventeenth century. By the end of the eighteenth century, England had colonies all over the world. English merchants profited from this development by exploiting international trade routes. The English Parliament strove to "encourage[ ] ... British shipping, and ... preserv[e] ... the colonial markets for Great Britain in such a way that the commercial interests both of the colonies and of Great Britain were secured."

\section{A. The Unique Structure of Maritime Relationships}

Maritime relationships reflected the extensive international system of which they were a part. Unlike most other business relationships in the sixteenth and seventeenth centuries, maritime relationships were not based on tightly-knit family and community connections. Instead, they involved the complete separation of ownership, management, and work, and were established by contracts rather than by more general moral or social sentiments."

Ship owners participated little, if at all, in their ships' upkeep or voyages. Owners generally contracted with masters who took responsibility for every aspect of a ship. Masters hired and supervised seamen and other service providers, made sure ships were in good repair, obtained provisions, and oversaw voyages.

To complete their responsibilities, masters frequently entered into contracts on behalf of ship owners. Masters entered into wage contracts to secure labor for voyages and into sales and service contracts for repairs and provisions. Additionally, masters had the authority to pledge owners' ships as collateral for securing loans. This authority,

9 William Holdsworth, 11 A History of English Law 407 (Little Brown 1938) (discussing the impact of the Navigation Act on English commerce and industry).

10 For a discussion of the connection between separated business relationships and a contract regime, see Grant Gilmore, The Death of Contract (Ohio 1974). For a description of the effects of more close-knit and local interactions, see Robert C. Ellickson, Order Without Law: How Neighbors Settle Disputes (Harvard 1991).

11 The phrase "separated ownership, management, and work" invokes a concept that Alfred Chandler used in his history of the development of business and industry. Chandler used the phrase to refer to corporate business relationships that developed during the middle of the nineteenth century and replaced smaller, localized family businesses. Though the correlation may not be perfect, for the purposes of this model, ship owners are owners, masters are managers, and mates and mariners are producers. See Alfred D. Chandler, Jr., The Visible Hand:The Managerial Revolution in American Business 9,87 (Belknap 1977). 
called "hypothecation," was important because it provided a way for masters to obtain money for necessary provisions and services when they could not contact ships' owners for more funds. ${ }^{12}$ Hypothecation was particularly necessary when, for instance, a ship was delayed or damaged by inclement weather, hijacked by pirates, or merely unequipped for the unprecedented distances to England's far-off colonies.

\section{B. Admiralty Court Jurisdiction over Seamen's Wage and Hypothecation Cases}

The contract structure that served as the basis for maritime relationships also, rather ironically, threatened to take these relationships outside the purview of Admiralty court jurisdiction. Admiralty courts had exercised wide and vaguely defined jurisdiction over maritime cases during the fourteenth and fifteenth centuries. ${ }^{13}$ However, by the end of the eighteenth century, these courts had been largely "confined to contracts and things exclusively made and done upon the high seas." ${ }^{14}$

The most important limitation on Admiralty jurisdiction was the Admiralty Jurisdiction Act of 1389 ("Act"), which limited Admiralty jurisdiction to "thing[s] done upon the sea." tial to eliminate Admiralty jurisdiction completely in seamen's wage

12 For example, in Menetone $v$ Gibbons, the master of a ship hypothecated a ship to individuals for "setting her forth to sea, and for furnishing and providing her with victuals." 3 Term Rep 267, 267, 100 Eng Rep 568 (KB 1789).

13 During the fourteenth and fifteenth centuries, as international trade and interest in the navy increased, Admiralty courts exercised wide and vaguely defined jurisdiction over criminal and civil matters and prize cases. Admiralty court jurisdiction extended over all contracts made abroad, bills of exchange, commercial agencies abroad, charter parties, insurance, non-delivery of or damage to cargo, negligent navigation, and breach of warranty of seaworthiness and other charter provisions. In addition, the court exercised jurisdiction over various torts committed on the sea, in public rivers, over cases of collision, salvage, fishermen, harbors and rivers, and occasionally over matters transacted abroad, but otherwise outside the scope of Admiralty jurisdiction. For a general discussion, see Holdsworth, 11 A History of English Law (cited in note 9).

14 See De Lovio v Boit, 7 F Cases 418, 426 (Cir Ct D Mass 1815) (discussing the original jurisdiction of Admiralty courts at common law):

[Admiralty courts have] no jurisdiction over torts, offences or injuries, done in ports within the bodies of counties, notwithstanding the places be within the ebb and flow of the tide; nor over maritime contracts made within the bodies of counties or beyond sea, although they are, in some measure, to be executed upon the high seas; nor of contracts made upon the high seas to be executed upon land, or touching things not in their own nature maritime, such as a contract for payment of money; nor of any contracts though maritime and made at sea, which are under seal or contain unusual stipulations; and to complete the ... disabilities ... that the admiralty is not a court of record, and of course has no power to impose a fine, and that it cannot take a recognizance or stipulation in aid of its general jurisdiction.

15 F.L. Wiswall, Jr., The Development of Admiralty Jurisdiction and Practice Since 1800:An English Study with American Comparisons 4 (Cambridge 1970) (discussing the 1389 Admiralty Jurisdiction Act's restriction on Admiralty jurisdiction). 
and hypothecation cases. Though maritime contracts contemplated "thing[s] done upon the sea," they were usually entered into on land and consequently were outside the scope of Admiralty jurisdiction recognized in the Act.

In seamen's wage cases, the Act interacted with two other statutes that regulated the form and timing of seamen's wage transactions. The first statute required all seamen's wage agreements to be made in writing. ${ }^{16}$ This statute was meant to protect mates and mariners from being cheated out of their wages. ${ }^{17}$ However, the combination of this statute and the Act could have eliminated mates' and mariners' ability to bring suit in Admiralty court-and to recover on wage agreements-because most seamen entered into their wage contracts on land, before voyages began. ${ }^{18}$

The second limitation on seamen's wage cases was a combination of maritime, statutory, and common law that controlled when mates and mariners could be paid. The legislature passed a law "to prevent masters paying seamen above one moiety of their wages due to them beyond the seas," ners could not take out insurance on their wages.

These laws were based on the principle that mates and mariners forfeited their wages if they left their ships before the completion of the voyages for which they had been hired. ${ }^{21}$ The laws did not directly affect the scope of Admiralty jurisdiction, but they increased the importance of providing mates and mariners with an adequate means of recovery because they raised the risk that seamen would be cheated "out of all of their wages, instead of merely a portion of them.

In hypothecation cases, the only relevant statute was one that vested in masters the right to "hypothecate [their ship] for necessaries $\ldots$ in the course of the voyage." The biggest limitation in hypotheca-

16 Id at 4-5. See Howe v Nappier, 4 Burrow 1944, 1947, 98 Eng Rep 13 (1766) (noting the statutory requirement that agreements be in writing).

17 Benzen $v$ Jeffries, 1 Lord Raymond 152, 91 Eng Rep 999 (KB 1697) (discussing a statute, 2 Hen 4 cap 11, that required seamen's wage contracts to be in writing). The writing requirement protected seamen by ensuring that owners and masters did not attempt to modify agreements after a voyage-in some ways akin to the modern statute of frauds. Additionally, it may have protected owners by documenting the agreements into which their masters entered. This was particularly important, given the dangers that mariners faced during voyages.

18 For a general discussion of the effects of statutory writing requirements, see Howe, 4 Burrow at $1950-51$.

19 King v Glover, 2 Bosanquet and Puller New Reports 206, 209, 127 Eng Rep 603 (Ex 1806 ) (relying on the purpose of the underlying statute to distinguish the insurances of wages between captains and mariners).

20 Id at 209.

21 See The "Pearl," 5 C Robinson 224, 222-25, 165 Eng Rep 756 (Instance Court 1804) (stating that "the legal consequence of desertion, in willfully quitting the services of the ship, before her arrival in port, is the forfeiture of wages").

22 Benzen, 1 Lord Raymond at 152 (prohibiting Admiralty jurisdiction over hypothecation 
tion cases was the practical considerations that surrounded hypothecation. Masters entered into hypothecation agreements to obtain necessities for troubled ships. Thus, by their very nature, hypothecation contracts were almost always entered into on land, rather than at sea.

If common law courts had stringently adhered to the Act and its limits on Admiralty jurisdiction to "thing[s] done upon the sea," it would have had the practical effect of barring masters from bringing suit in Admiralty court for hypothecation agreements. The King's Bench recognized this possibility in Benzen $v$ Jeffries $^{23}$ when it stated, "as to the objection, that the contract was made upon the land, and the money paid there; it must of necessity be so, for if a man be in distress upon the sea, and compelled to go into port, he must receive the money there, or not at all.",24

\section{PRESERVATION OF AdMIRALTy JuRISDICTION IN SEAMEN'S WAGE AND HYPOTHECATION CASES}

In seamen's wage and hypothecation cases, common law courts avoided the presumptive result of the Act, which limited Admiralty jurisdiction to acts done at sea, and considered the nature of the acts, not their location. They recognized Admiralty courts' jurisdiction when certain requirements concerning agreement form and claimant status were met, even when the courts would have prohibited Admiralty jurisdiction in other types of cases. ${ }^{25}$ Common law courts had the power to prevent Admiralty courts from exercising-or exceedingtheir jurisdiction by issuing writs of prohibition during a suit for prohibition that could be brought by either party involved in a noncommon law suit. Common law courts decided whether to grant a prohibition, forbidding the Admiralty suit from proceeding, after hearing the parties' arguments about whether the case was beyond the Admiralty court's jurisdiction. ${ }^{26}$

contract entered into in London, but recognizing masters' right to hypothecate "if his ship be impaired by tempest, so that he is forced to borrow money to refit, otherwise she will be lost").

231 Lord Raymond 152, 91 Eng Rep 999 (KB 1697).

24 Id.

25 See Howe v Nappier, 4 Burrow 1944, 1950-51, 98 Eng Rep 13 (KB 1697).

26 See generally Gray, 1 The Writ of Prohibition (cited in note 7). Prohibition suits could be initiated by any person generally eligible to bring a lawsuit; one did not have to be a defendant or have any interest in the suit one sought to arrest. To stop a suit in a non-common law court on the grounds that it was beyond the court's jurisdiction, the plaintiff-in-prohibition went to the King's Bench or Common Pleas with his statement of cause. Defendants-in-prohibition had a right to contest a prohibition by addressing the legal or factual matters of the underlying case or by challenging the prohibition itself. What a plaintiff-in-prohibition hoped to accomplish if he succeeded varied with the circumstances. The party may have wanted to escape liability entirely, to force the other party to bring a new suit at common law, or to secure trial by the common law method of a jury or decision of legal question by common law judges. 
Writs of prohibition were potentially an extremely potent means of limiting Admiralty jurisdiction because they provided a mechanism for common law courts to define the scope of their non-common law competitors' jurisdiction. ${ }^{27}$ The power that writs of prohibition afforded common law courts made the courts' restraint all the more striking.

The courts recognized this inconsistency and stated that seamen's wage and hypothecation cases could be brought in Admiralty only by grace of the common law courts. ${ }^{23}$ Common law judges justified preserving Admiralty jurisdiction in these cases by discussing the procedural advantages Admiralty courts provided-such as the fact that Admiralty courts allowed for in rem and multiparty actions, while common law courts limited their proceedings to in personam actions brought by individual claimants. ${ }^{29}$ Multiparty actions were valuable because they allowed parties lacking the resources, information, or incentives to bring suit on their own to join with other claimants who were similarly situated. Thus, such actions were akin to modern class actions.

Admiralty jurisdiction provided a way for common law courts to facilitate certain types of maritime relationships. The procedural advantages of Admiralty courts provided seamen with the incentives and opportunities to enforce wage agreements by making it easier than in common law courts to collect damages and to bring suit. By providing these mechanisms, Admiralty courts increased the probability that wage contracts could be enforced. This was extremely important, particularly given the fact that maritime relationships were almost entirely based on contracts.

Admiralty courts also had rules that protected owners from some of the risk created by giving masters authority over their business operations and contract obligations. These rules helped distribute some

27 As the United States Supreme Court observed in 1827, “[T]he Court of the King's Bench, by its acknowledged jurisdiction, as exemplified in the very exercise of its power to prohibit, is the very source to which we are to look for lights to determine the respective powers of the inferior Courts." Ramsay v Allegre, 25 US 611,621 (1827).

28 See, for example, Holland v Money Arising from the Sale of the "Royal Charlotte," 1 Burrell 76, 77 (Admiralty 1768), in Reginald G. Mardsen, ed, Reports of Cases Determined by the High Court of Admiralty 76,77 (William Clowes and Sons 1885) (discussing dispute arising after master advanced money to pay seamen's wages after "ship was sold by decree of [Admiralty] Court").

29 Menetone $v$ Gibbons, 3 Term Rep 267, 267, 100 Eng Rep 568 (KB 1789) (stating that Admiralty courts "have cognizance of an hypothecation bond given in the course of a voyage, though it be executed on land and under seal"); Clay v Snelgrave, 1 Lord Raymond 576, 577, 91 Eng Rep 1285 (KB 1700) (stating that "the great reason why they are permitted to sue there is, the ship is the debtor, and by the law of the Admiralty they may attach her, which they cannot do by the common law; and in the Admiralty court they may all join in a suit, whereas by the common law they must bring several actions").

30 See Part I for discussion of the importance of contracts in maritime relationships. 
of the risks created by the unique structure of maritime relationships. For example, the Admiralty rule that suits could be brought against masters, ships, and cargo, but not against ship owners themselves, limited owners' liability to the value of the ship and its cargo. ${ }^{31}$ This amount was what owners probably, and rationally, would have invested. ${ }^{22}$ Another Admiralty rule stated that claimants could attach masters to Admiralty claims. ${ }^{33}$ By making masters personally liable if they entered into agreements that were worth more than the value of the ship and its cargo, this rule checked masters' willingness to enter into unduly burdensome or extravagant contracts. ${ }^{34}$

Ultimately, Admiralty jurisdiction allowed common law courts to facilitate certain types of maritime relationships and to define and limit the authority, rights, and duties of maritime personnel. This recognition and facilitation was particularly important, given the central role that contracting had in defining maritime relationships. These dual concerns are evidenced in the framework common law courts developed to define Admiralty jurisdiction in both seamen's wage and hypothecation cases.

\section{A. Seamen's Wage Cases}

To determine Admiralty jurisdiction in seamen's wage cases, common law courts considered the status of the claimants and the form and substance of the agreements. They recognized Admiralty jurisdiction in suits brought by mariners and those that involved ordinary wage contracts, but prohibited Admiralty jurisdiction, and exercised common law jurisdiction, in suits brought by masters or that involved special or sealed agreements. The former distinction can be understood as a way of facilitating certain types of maritime relationships, while the latter makes sense as a way to check masters' ability to enter into idiosyncratic and unforeseeable contracts to the detriment of owners.

31 See, for example, Ross $v$ Walker, 2 Wilson Rep 264 (KB 1765).

32 From a theoretical standpoint, this amount should approximate the optimal level of investment for owners to make in the ship and its cargo. This level is optimal because ship owners, like stockholders of a corporation, would desire limited liability when business decisions are being made by agents (masters or CEOs, respectively) that the owners cannot easily monitor. See Posner, Economic Analysis of Law at $\$ 1$ (cited in note 8).

33 See, for example, "The Favorite," 2 C Rob 232,165 Eng Rep 299 (Instance Ct 1799).

34 The fact that masters could be attached to Admiralty cases, but not common law cases, may have created perverse incentives and encouraged masters to enter into nonstandard agreements to avoid Admiralty jurisdiction and the risk of being attached to a claim. This problem could not be completely eliminated, but its effects were minimized by the fact that it was difficult for claimants to maintain common law actions. The difficulty of sustaining common law actions created an incentive for mates and mariners to monitor masters by ensuring that they entered into standard agreements and reduced the risk that owners would be charged in common law actions. 


\section{Claimant status: the master-mariner distinction.}

Common law courts made sharp and rigid distinctions between masters, on the one hand, and mates and mariners, on the other, and severely restricted the ability of the masters to bring suit in Admiralty courts. They recognized Admiralty jurisdiction when "mariners sue[d] in the Admiralty for wages ... [even if the agreement] is pleaded to have been made at land,", but not over "contract[s] made with the master upon the land." ${ }^{36}$ Masters, unlike other maritime personnel, generally had to bring suit in common law court to recover wages. Despite its facial simplicity, this distinction was difficult to administer because it required common law courts to define the categories of mates, mariners, and masters. These categories, as discussed below, were not always clearly divided and thus the common law courts also had to determine what to do when claimants did not fit into the typical mold of mate, mariner, or master.

Common law courts classified a broad range of claimants as mates or mariners and allowed them to sue in Admiralty courts. Examples of such individuals include boatswains, ${ }^{37}$ pilots, ${ }^{38}$ seamen hired to fit a ship for sea even if the ship never ultimately proceeded upon the voyage, ${ }^{39}$ mates who were "not in nature ... a mariner, but [were] to succeed the master, if he died in the voyage, ${ }^{, * 0}$ surgeons, ${ }^{41}$ and carpenters. ${ }^{42}$

Common law courts rigidly maintained the distinctions that they developed. Many cases arose involving claimants who initially served

35 Buck v Atwood, 2 Strange 761, 761, 93 Eng Rep 832 (KB 1727) (refusing to prohibit Admiralty jurisdiction, despite argument that "deed [was] pleaded to have been made at land").

36 Justin v Ballam, 2 Lord Raymond 805, 806, 92 Eng Rep 38 (KB 1702) (holding that Admiralty courts did not have jurisdiction over a suit brought by a master regarding a contract made upon land). See also Clay v Snelgrave, 1 Lord Raymond 576, 576, 91 Eng Rep 1285 (KB 1700) ("The master of a ship cannot sue in the Admiralty for his wages on a contract made on shore.").

37 Ragg $v$ King, 1 Barnardiston Rep 297, 94 Eng Rep 202 (KB 1729) (discussing suit brought for wages by a master and boatswain). A boatswain is a petty officer on a merchant vessel who is in charge of rigging, anchors, cables, etc. Gove, ed, Webster's Third New International Dictionary at 244 (cited in note 4).

38 Ross $v$ Walker, 2 Wilson Rep 264 (KB 1765) (holding that pilots are mariners and can bring suit in Admiralty court, but granting a writ because the pilot worked within the body of the country).

39 Wells v Osman, 2 Lord Raymond 1044, 92 Eng Rep 193 (KB 1704) (permitting seaman's suit for wages in Admiralty court).

40 Bayly $v$ Grant, 1 Salkeld 33,33,91 Eng Rep 35 (KB 1701) (holding that a mate of a ship may sue for wages in Admiralty court). See also Hook v Moreton, 1 Lord Raymond 397, 398, 91 Eng Rep 1165 (KB 1698) (stating that "it seemed to the Court, that a mate is but a mariner" when finding that a mate can sue in Admiralty for his wages).

41 Mills $v$ Long, Sayer 136, 96 Eng Rep 829 (KB 1754) (holding that a surgeon of a ship may sue in Admiralty court).

42 Id at 137 (comparing a surgeon's obligation to the master to that of the ship's carpenter). 
as mariners and were subsequently promoted to master. Common law courts allowed claimants who served in dual roles to sue in Admiralty court for wages they earned as mates or mariners, but not for what they earned as masters, even when the suit for masters wages "was only an incident to the other."

For example, in Reed $v$ Chapman, the common law court did not allow the Admiralty court to exercise jurisdiction in a claim for wages brought by a former mate who took over as master after the original master of the ship died during the voyage. ${ }^{45}$ The court relied on the rule that "for wages of mariners or mates of ships the Admiralty Court shall be allowed jurisdiction, but for wages of masters they shall not" and allowed Admiralty jurisdiction in the suit for wages earned as a mariner but not for those as a master."

Similarly, in The "Favourite," the court did not allow the Admiralty court to exercise jurisdiction over a claim brought by a former mate who became a master when the initial master was taken hostage by a French privateer. The former master had been unable to discharge several bonds to finance the voyage after the ship was in distress. The privateer captured the previous master, who was personally liable for the bonds, and released the ship, and the previous master asked the claimant to serve as master during the former's detention. The common law court held that the claimant was "entitled to his wages as mate, and that he must go elsewhere for the reward of the additional services performed as master."

Initially, the dual system of recovery for parties that served as both mariners and masters does not seem to make sense. It seems like a waste of judicial and individual resources to require parties to bring two separate suits to recover their wages. However, the dual system fit well with the structure of maritime relationships and the fact that masters contracted directly with owners and oversaw ships' operations.

Common law courts frequently justified allowing mates and mariners, but not masters, to benefit from Admiralty procedures by referring to the structure of maritime relationships. They focused on the fact that masters contracted directly with ship owners, while mates and mariners were dependent on their masters for wages.

43 Reed $v$ Chapman, 2 Barnardiston Rep 160, 160, 94 Eng Rep 421 (KB 1732) (prohibiting Admiralty jurisdiction for wages that the plaintiff, who had previously been a mate, earned when he replaced a master who died during the voyage).

442 Barnardiston Rep 160,94 Eng Rep 421 (KB 1732).

45 Id.

46 Id.

472 C Rob 232, 165 Eng Rep 299 (Instance Ct 1799).

48 Id at 238. 
In Ross $v$ Walker, ${ }^{49}$ the court stated that pilots were mariners and could sue in Admiralty court (absent an expired statute of limitations) because "the master covenants with the owners to find a pilot, and they to pay him.."so The court went on to say that pilots should be able to sue in Admiralty court "out of compassion to these poor men that they may all join in the court of Admiralty; they do not know who is the master, or is to pay them, so they proceed against the ship."st

Similarly, in King v Glover, ${ }^{\text {sh }}$ one of the justices stated:

Indeed the captain and the mariners are treated as very different subjects of consideration in the marine law; the former are supposed to be persons of trust and confidence with the owners, and to be bound to them by the terms of their contract, nor is there any fear that they will run away or desert; and so far is the idea of personal trust and confidence between the owners and the master carried, that the latter has not, as the mariners have, the choice of proceeding against the ship in the Admiralty, or suing at law, but must pursue his remedy at law; moreover he is considered quasi owner himself, and liable to be tried. ${ }^{s 3}$

Likewise, in Wells $v$ Olsman, ${ }^{\text {s4 }}$ the justices focused on the differences between the relationships that mates and masters had with ship owners. One justice described the role of seamen that "they look no farther [than the voyage], they do not concern themselves with the property of the ship, nor are privy to the bill of sale, or any other matters between the master and the builder; and therefore it would be hard for any thing that passes between the master and the builder to take away their remedy."

The distinction that common law courts made between masters and other maritime personnel makes sense when Admiralty jurisdiction is analyzed as a way to facilitate certain types of contractual relations. Common law courts were concerned that mates and mariners would not be allowed to recover if they were not allowed to bring multiparty or in rem suits, particularly since mates and mariners did not have any contact with the owners on whose ships they worked.

If mates and mariners were not allowed to bring suit in Admiralty court, there was a chance that the wage contracts would be unenforceable because common law courts did not allow in rem or multi-

492 Wilson Rep 264 (KB 1765).

50 Id at 265 .

51 Id.

522 Bos \& Pul (NR) 206, 127 Eng Rep 603 (Ex 1806).

53 Id at 210.

542 Lord Raymond 1044, 1044, 92 Eng Rep 193 (KB 1704).

55 Id at 1045 (holding that a seaman hired to fit a ship for sea and go on a voyage may sue in Admiralty court even though the ship did not ultimately proceed upon the voyage). 
party actions (both of which helped seamen recover). This could seriously disrupt the maritime industry-both by making mates and mariners unwilling to sign contracts on land, which would be extremely inconvenient, and by allowing owners to externalize costs by cheating their personnel out of wages.

The same concerns did not exist with masters. Most ships had only one master, and most masters contracted directly with ship owners. This meant that the primary reasons for allowing mates and mariners to bring suit in Admiralty court did not apply to masters. First, since there was only one master on a ship, masters did not require, nor would they benefit from, multiparty actions. Second, since masters' contracts generally conformed with standard agreements in which the parties knew one another, the same concerns that supported affording mates and mariners the protection of in rem actions did not apply. Common law courts had no reason to allow masters to bring suit in Admiralty court to recover wages, since allowing such jurisdiction would not facilitate or support masters' contractual relations.

\section{Substance and form requirements.}

To determine how to classify claimants, common law courts generally focused on written agreements, rather than on what jobs the claimants actually performed. This approach served an evidentiary function, allowing courts to focus on something tangible and avoid struggling to sort out contradictory testimony.

Courts often described their classifications in terms of whether written agreements were parol agreements, which merely supported standard wage agreements, or whether they were special or sealed agreements, which contemplated extra or unique obligations. They allowed Admiralty courts to exercise jurisdiction over the former but not the latter.

The distinction between standard and special agreements is illustrated by a comparison between Bens $v$ Parre ${ }^{56}$ and Opy $v$ Child." In $B e n s$, the court recognized Admiralty jurisdiction over an agreement that the petitioner alleged "was made by deed at land" even though the contract was "by writing, and yet not by deed" on the grounds that "notwithstanding the writing, it is but a parol contract." In contrast, in $O p y$, the court stated that Admiralty jurisdiction should be prohibited since "there ... [was a] special agreement by which the mariners ... receive[d] their wages in any other manner than is usual; or ... the

562 Lord Raymond 1206, 92 Eng Rep 296 (KB 1705).

571 Salkeld 31,91 Eng Rep 33 (KB 1795).

582 Lord Raymond at 1206.

59 Id. 
agreement ... [was] under seal, so as to be more than a parol agreement."

The distinction paralleled the statutory requirement that seamen's wage contracts must be in the form of written agreements. By preserving Admiralty jurisdiction over standard agreements, common law courts ensured that seamen were not precluded from benefiting from the procedural advantages of Admiralty courts merely because they adhered to the statutory requirement that they enter written wage contracts instead of oral agreements. ${ }^{61}$ However, despite this correlation, no clear guidelines existed to differentiate standard and special agreements, and it is difficult to derive meaningful distinctions from these cases because courts generally did not outline the facts that underlay disputes. ${ }^{62}$

Common law courts emphasized written agreements in a way that allowed them to protect maritime personnel and owners from some of the risks caused by the unique structure of maritime relations. By focusing on written agreements, instead of actual performance, the courts shielded mates and mariners from some of the problems that arose between masters and owners. For example, in Wells $v$ Osman, ${ }^{63}$ the claimants were "hired to fit a ship for sea and go a voyage in her,", but the ship never sailed because the agreement between the intended master and the owners fell through. The court upheld the claimants' right to "sue in the Admiralty ... tho' she does not proceed upon the voyage... . [as long as the owner] permit[ted] them to go on board." "s This ensured that maritime personnel would not be penalized for entering into contracts with masters rather than owners, as mandated by industry practice.

Correspondingly, common law courts also protected owners from potentially idiosyncratic contracts that masters could develop according to their own interests and whims. For example, in The "Mona, ",66 the court held that Admiralty courts did not have jurisdiction over an agreement in which the claimant agreed to stay with the ship throughout its voyage and "pull a rope when [the master did]." ${ }^{67}$ The court found that the contract "directly stated, that he was not to be required to perform a mariner's duty at all," and that "where there is a special

601 Salkeld at 31, 91 Eng Rep at 33.

61 For a discussion of the procedural advantages, see text accompanying note 29.

62 This difficulty is demonstrated by the impossibility of distinguishing Bens $v$ Parre and Opy v Child. In both decisions, the courts issued their opinions without outlining the facts. This lack of description is common in most opinions of this period.

632 Lord Raymond at 1044.

64 Id.

65 Id.

661 W Rob 137, 166 Eng Rep 524 (Admiralty 1840).

67 Id at 140. 
agreement differing from the ordinary mariner's contract, [Admiralty] Court has no power to adjudicate." ${ }^{\sharp 8}$ This ensured that wage agreements accorded with owners' reasonable expectations and subsequently reduced the risks associated with allowing masters to enter into contracts on owners' behalf.

Both Wells and "Mona," despite their different results, protected mariners and owners from the unprecedented authority that masters had as a result of the unique structure of maritime relations. This protection was extremely important. Maritime relationships-which involved the complete separation of ownership, management, and work-represented a new type of relationship in sixteenth- and seventeenth-century England. ${ }^{69}$ Protections like those in Wells and "Mona" facilitated these relationships by minimizing some of their costs (and some disincentives for entering into such relationships).

\section{B. Masters' Hypothecation Cases}

Hypothecation cases often arose when ship owners tried to avoid honoring the agreements that masters entered into to obtain goods and supplies during a voyage. One such case, Menetone $v$ Gibbons, arose after individuals attempted to sell a ship that a master had hypothecated in exchange for providing his ship "with victuals and other necessaries and materials, for enabling her to prosecute her voyage with safety." The owners argued that the contract was invalid because it had been created under the master's seal, rather than under the owner's. However, the court, recognizing the master's authority to enter into hypothecation agreements, held that the plaintiffs had the title to the ship free and clear.

In hypothecation cases, common law courts developed an exception that paralleled the exception in seamen's wage cases to the requirement that Admiralty jurisdiction could only be exercised over things done upon the sea. The basic rule in such cases was that Admiralty courts had "cognizance of an hypothecation bond given in the course of a voyage, though it be executed on land and under seal."." For example, in Menetone, the court upheld Admiralty jurisdiction (and the Admiralty court determination that the hypothecation contract was valid) even though the hypothecation agreement was entered into on land. ${ }^{74}$

68 Id at 141

69 See Part I.A for a discussion of the unique structure of maritime relationships.

703 Term Rep 267, 100 Eng Rep 568 (KB 1789).

71 Id.

72 Id.

73 Id.

74 Id. 
However, the scope of Admiralty jurisdiction in hypothecation suits was different from the scope of jurisdiction in seamen's wage cases. ${ }^{75}$ The primary limitation that common law courts placed on Admiralty jurisdiction in hypothecation cases was the rule that masters did not have power "to hypothecate the ship in port, before she set out upon her voyage. ${ }^{, 76}$ Common law courts treated hypothecation agreements entered into before the ship went on voyage as standard contracts and applied the basic guideline that Admiralty courts could not exercise jurisdiction over contracts that were not "done upon the sea."

In Justin v Ballam, ${ }^{n}$ which involved a contract to supply an anchor and cable to a distressed ship, the court stated that it did not appear "that the ship was in her voyage, when she became in distress." The court therefore held that

it is true, that by the maratime law every contract with the master of a ship implies an hypothecation; but it is otherwise by the law of England. Therefore this being a contract made with the master upon the land, it is the common case. The admiralty cannot have cognisance of such a suit. ${ }^{79}$

This differed from seamen's wage agreements, in which common law courts allowed seamen to bring suit, even for wages the claimant earned before the voyage began.

The relative simplicity of hypothecation cases, as compared to seamen's wage cases, was partly a function of the nature of hypothecation. Courts did not have to develop fine-tuned distinctions among maritime personnel because, as a practical and statutory matter, only masters could hypothecate a ship during its voyage. Additionally, courts could not practicably limit Admiralty jurisdiction over hy- . pothecation agreements to standard, unsealed contracts. By their very nature, hypothecation contracts were special because masters entered into them out of necessity when a ship was in distress. Moreover, the third parties with whom such agreements were entered into may have required them to be under seal, particularly if the masters were unknown foreigners.

As with seamen's wage contracts, common law courts defined Admiralty jurisdiction in hypothecation cases in a way that jointly facilitated and limited masters' ability to enter into such agreements.

75 Id.

76 Lister v Baxter, 2 Strange 695, 695, 93 Eng Rep 789 (KB 1729).

772 Lord Raymond 805, 92 Eng Rep 38 (KB 1702).

78 Id.

79 Id.

$80 \quad$ See note 39 . 
Common law courts often justified recognizing Admiralty jurisdiction over hypothecation contracts by emphasizing the importance of providing a remedy for contracts that the law explicitly authorized masters to enter into and that were important to the maritime industry. For example, in Benzen, ${ }^{81}$ the court recognized Admiralty jurisdiction over a contract in "which the master had hypothecated for necessaries, being upon the sea in stress of weather." It stated that "since the King's Bench cannot do right to the parties, it will not hinder the Admiralty from doing them right. For if the King's Bench allows the hypothecation, and yet denies the remedy, it will be a manifest contradiction.",

However, common law courts did not allow Admiralty courts to exercise jurisdiction when masters were in a position to seek authorization from owners before entering into agreements. For example, in Justin, ${ }^{\text {s4 }}$ the court prohibited Admiralty jurisdiction over a hypothecation contract that the master entered in port before the voyage began. This meant that the master could not bring an in rem action, even though the master "would be without remedy."

The rule that Admiralty jurisdiction was appropriate for hypothecation contracts entered during voyages but not for those entered before voyages began can be considered as a way to balance the need for masters to raise money against owners' interest in being consulted.

\section{WHY COMMON LAW COURTS PRESERVED ADMIRALTY JURISDICTION}

Courts generally described the benefits of Admiralty jurisdiction by making broad statements about fairness or legislative intent. However, neither of these explanations fully accounts for the complex framework common law courts developed to define Admiralty jurisdiction in seamen's wage and hypothecation cases. Ultimately, the

811 Lord Raymond 152.

82 Id.

83 Id (deciding action brought under statute 2 Hen 4, cap 11, which created a right to sue for recovery on hypothecation agreements). As a justice in Menetone stated:

That the master of the ship should have power to take up money on hypothecation for necessaries for a ship, when she is on the voyage, seems highly necessary. The law has so established it, convenience requires it, and the naval power of this country, as far as it depends on individuals, is concerned in the continuance of it.

3 Term Rep at 269. See also Benzen, 1 Lord Raymond at 152-53 (stating, "[Of] the objection, that the contract was made upon the land, and the money paid there; it must of necessity be so, for if a man be in distress upon the sea, and compelled to go into port, he must receive the money there, or not at all. And if his ship be impaired by tempest, so that he is forced to borrow money to refit, otherwise she will be lost, and for security of this money he pledges his ship; since the cause of the pledging arises upon the sea, the suit may well be in the Admiralty Court.").

8492 Eng Rep 38. 
common law framework suggests that common law courts defined Admiralty jurisdiction in seamen's wage and hypothecation cases in a way that supported standard maritime business practices and fostered productive economic relationships.

\section{A. Common Law Justifications: Fairness and Legislative Intent}

A few courts emphasized fairness and suggested that it was important to ensure that every right had a practicable means of recovery. For example, in Ross $v$ Walker, the court discussed the importance of allowing mates and mariners, who were probably unable to maintain individual actions, to bring multiparty actions. The court upheld the distinction between mates and mariners on the grounds that it would be "very hard" if "40 ... [were] obliged to bring several suits at common law." "s6

Other courts emphasized the need to ensure recovery in a way that was consistent with legislative intent. An example of this limitation is Howe $v$ Nappier, ${ }^{87}$ in which the court cited the statute that directed that "agreements shall be in writing"ss and stated that the legislature "did not mean to take away the Admiralty jurisdiction, so convenient to mariners. And surely the mere putting a seal to the agreement in writing ought not to take their jurisdiction away from them.,

However, there are problems with both the fairness and legislative intent arguments. The fairness argument does not explain why common law courts did not merely modify their own procedures to allow multiparty actions or why they developed a complex framework that did not permit all parties to recover. Likewise, the legislative intent argument is not supported by evidence that the legislature intended to preserve Admiralty jurisdiction in seamen's wages and hypothecation cases. In fact, available evidence regarding legislative intent, involving the political environment and status of common law courts after the English Revolution, contradicts this argument."

852 Wilson Rep 264.

86 Id at 265. See note 83 and accompanying text.

874 Burrow 1944, 98 Eng Rep 13 (1766).

88 Id at 1947.

89 Id.

90 The desire to be fair, and provide easy and effective mechanisms for relief, does not explain why common law courts limited Admiralty jurisdiction (and made it more difficult to recover wages) in a number of cases-such as cases involving masters' wage claims or special, sealed agreements, and hypothecation agreements that masters entered before voyages began. For examples of limits, see Reed, 2 Barnardiston Rep 160 (allowing claimant to sue in Admiralty court for wages earned as a mate or mariner but not for wages earned as a master); "Mona," $1 \mathrm{~W}$ Rob 137 (holding that the Admiralty court did not have jurisdiction over a mariner's claim for wages founded on a special agreement); Lister v Baxter, 2 Strange 695, 93 Eng Rep 789 (KB 1729) (holding that a master cannot hypothecate the ship before the voyage). See also Part II.

91 Indeed, the political environment during the 1700s supported the holding that the legis- 
B. An Alternative Explanation: Institutional Competence

An alternative explanation for why common law courts preserved Admiralty jurisdiction in seamen's wages and hypothecation cases is that common law judges wanted to support standard maritime business practices and recognized that Admiralty courts were better equipped than common law courts to do so.

Common law courts frequently discussed the unique relationships among mates and mariners, masters, and owners in seamen's wage and hypothecation cases. Examples from this Comment, expressing such concern, include Ross, in which the court emphasized that masters, and not mariners, entered into covenants with owners; ${ }^{92}$ King, in which the court stated that masters and mariners are treated differently because the former are in a position of trust with the owners, while there is a fear that mates and mariners will disobey; ${ }^{93}$ Wells, in which the court focused on the fact that mates and mariners, unlike masters, looked no further than the voyage and were not part of the contractual arrangements with the owners; ${ }^{94}$ and Benzen, in which the court argued that giving masters the right to hypothecate was essential because of the unique structure of maritime relations.

It makes sense that common law courts wanted to respect the unique structure of maritime relationships in seamen's wage and hypothecation cases. During this period, from after the English Revolution until the nineteenth century, society began to think that politics should accommodate business, rather than vice-versa. A number of scientific discoveries and mechanical inventions increased the importance of commerce and industry. These changes had a profound effect on England's political and social life and fundamentally transformed the relationship between business and politics. In this context, the newly created class of capitalists fought against "traditional [medieval legal] restrictions" and sought to "bring the law more closely into conformity with their economic practices."

lature wanted to limit Admiralty jurisdiction. For a description of the relationship between Admiralty courts and the Executive and the animosity created in Parliament towards Admiralty courts, see E.S. Roscoe, A History of the Prize Court 41-42 (Lloyd's 1924).

922 Wilson Rep at 265.

932 Bos \& Pul (NR) at 209.

942 Lord Raymond at 1044.

951 Lord Raymond at 152.

96 Production capacities and industrial relationships were transformed in agriculture, with new modes of husbandry and breeding and machinery like the drill-plough; in manufacturing, with new machinery; and in the textile, coal, and transportation industries, with the development of the steam engine. See William Holdsworth, 11 A History of English Law 390 (London 5 th ed 1942).

97 Thomas Wilson, A Discourse Upon Usury 135 (Harcourt Brace R.H. Tawney, ed 1572). 
The suggestion that common law courts were concerned with respecting the structure of the maritime industry is further supported by their willingness to recognize Admiralty jurisdiction. During this period, there was a general sense that Admiralty courts were better equipped to deal with the unique structure and practices of the maritime industry. ${ }^{98}$ Many agreed that the Admiralty process was more efficient and Admiralty judges were better equipped to decide cases involving contracts made abroad."

The fact that common law courts refused to prohibit Admiralty jurisdiction, despite explicit statutory text to the contrary, suggests that common law courts recognized that there was something unique and important to protect in the maritime industry. In these cases, common law courts treated jurisdiction as a flexible concept. They departed from the text of the Act and defined jurisdiction according to where maritime contracts were performed, rather than where they were executed-even when it meant expanding non-common law jurisdiction at their own expense. ${ }^{100}$

By departing from the statutory scheme, the courts allowed maritime cases to be heard in courts that were better equipped to deal with unique aspects of the industry. This delegation enabled the legal system to develop a scheme of remedies for seamen's wage and hypothecation cases that supported productive business practices and mitigated the risks created by the structure of maritime relationships.

\section{CONCLUSION}

Seamen's wage and hypothecation cases contradict the popular assumption that common law judges wanted to expand their own courts' jurisdiction. In these cases, common law judges developed a complex framework to preserve Admiralty jurisdiction, even though the Admiralty Jurisdiction Act of 1389 , along with numerous statutory and practical considerations, supported common law jurisdiction. One

98 See, for example, Howe, 4 Burrow at 1945-46 ("We can give the mariners the most effectual remedy in cases of wages. We can send commissions to examine witnesses: which foreign Courts of Admiralty will assist. Mariners may join together in suing, in our Courts. We examine our witnesses upon interrogatories: which is convenient to men of that vague kind of life. So that they have certain and convenient justice in Admiralty-Courts."); Pierce v Hopper, 1 Strange 249, 93 Eng Rep 503 (KB 1720) (declaration for attachment in prohibition).

99 For example, Admiralty courts could examine witnesses abroad, hear in rem proceedings against ships, and join suits by multiple mariners for wages into a single action. In contrast, common law courts required separate actions. See note 29 and accompanying text.

100 The concern common law courts demonstrated for maritime relationships can not be reconciled with the well established model that common law courts were merely concerned with retaining their own jurisdiction. Common law courts may have recognized Admiralty jurisdiction in seamen's wages and hypothecation cases merely as a way to be unobtrusive and avoid disrupting maritime relationships so much that Parliament would repeal the Admiralty Jurisdiction Act altogether. 
explanation for why common law courts preserved Admiralty jurisdiction is that common law courts wanted to facilitate productive maritime relationships. This possibility casts doubt on the notion that common law judges myopically clung to their own jurisdiction without considering the benefits of their non-common law counterparts. 


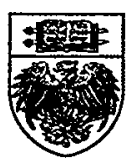

